UCRL-ID-141864

\title{
Earthquake Focal Parameters and Lithospheric Structure of the Anatolian Plateau from Complete Regional Waveform Modeling
}

\author{
Arthur Rodgers \\ Lawrence Livermore National Laboratory \\ Livermore, CA 94551
}

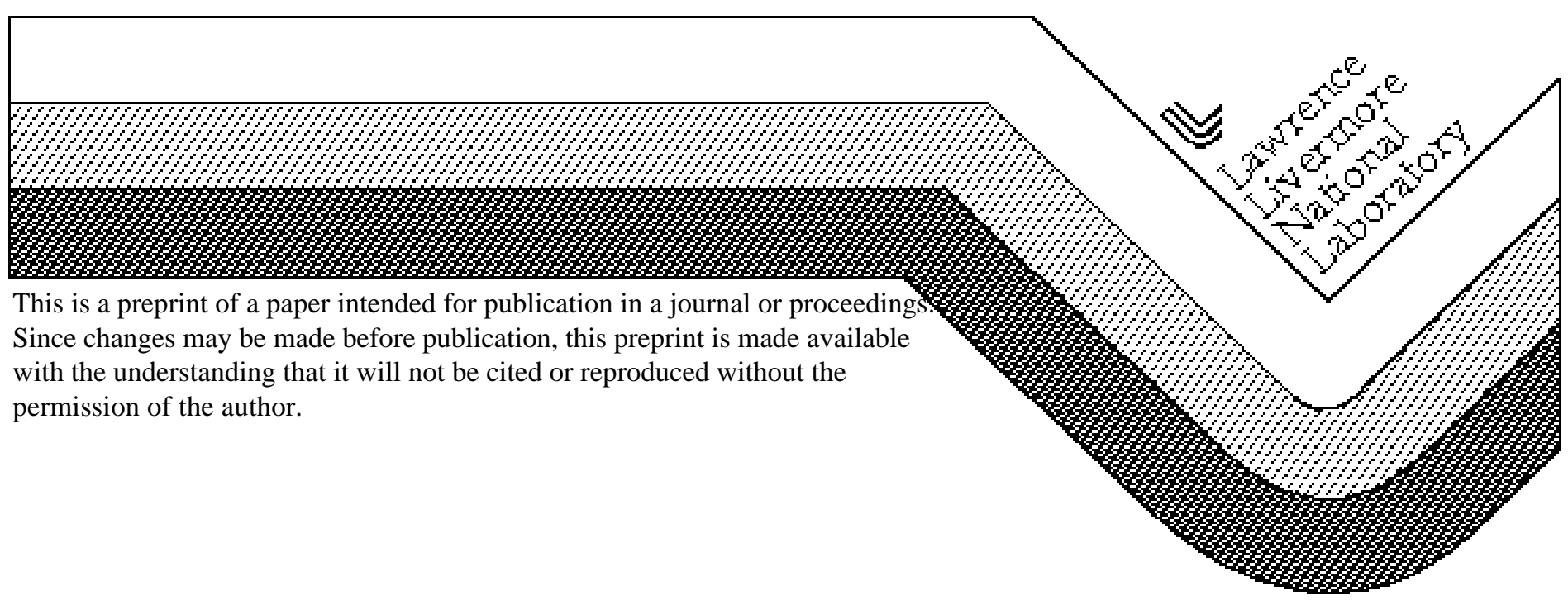




\section{DISCLAIMER}

This document was prepared as an account of work sponsored by an agency of the United States Government. Neither the United States Government nor the University of California nor any of their employees, makes any warranty, express or implied, or assumes any legal liability or responsibility for the accuracy, completeness, or usefulness of any information, apparatus, product, or process disclosed, or represents that its use would not infringe privately owned rights. Reference herein to any specific commercial product, process, or service by trade name, trademark, manufacturer, or otherwise, does not necessarily constitute or imply its endorsement, recommendation, or favoring by the United States Government or the University of California. The views and opinions of authors expressed herein do not necessarily state or reflect those of the United States Government or the University of California, and shall not be used for advertising or product endorsement purposes.

This is a preprint of a paper intended for publication in a journal or proceedings. Since changes may be made before publication, this preprint is made available with the understanding that it will not be cited or reproduced without the permission of the author.

This work was performed under the auspices of the United States Department of Energy by the University of California, Lawrence Livermore National Laboratory under contract No. W-7405Eng-48.

This report has been reproduced directly from the best available copy.

Available electronically at http://www.doc.gov/bridge

Available for a processing fee to U.S. Department of Energy

And its contractors in paper from

U.S. Department of Energy

Office of Scientific and Technical Information

P.O. Box 62

Oak Ridge, TN 37831-0062

Telephone: (865) 576-8401

Facsimile: (865) 576-5728

E-mail: reports@adonis.osti.gov

Available for the sale to the public from

U.S. Department of Commerce

National Technical Information Service

5285 Port Royal Road

Springfield, VA 22161

Telephone: (800) 553-6847

Facsimile: (703) 605-6900

E-mail: orders@ntis.fedworld.gov

Online ordering: http://www.ntis.gov/ordering.htm

OR

Lawrence Livermore National Laboratory

Technical Information Department's Digital Library

http://www.llnl.gov/tid/Library.html 


\title{
Earthquake Focal Parameters and Lithospheric Structure of the Anatolian Plateau from Complete Regional Waveform Modeling
}

\author{
Arthur Rodgers \\ Lawrence Livermore National Laboratory \\ L-205, Livermore, CA 94551 \\ rodgers7@llnl.gov \\ (925)-423-5018 \\ UCRL-ID-141864
}

\begin{abstract}
This is an informal report on preliminary efforts to investigate earthquake focal mechanisms and earth structure in the Anatolian (Turkish) Plateau. Seismic velocity structure of the crust and upper mantle and earthquake focal parameters for event in the Anatolian Plateau are estimated from complete regional waveforms. Focal mechanisms, depths and seismic moments of moderately large crustal events are inferred from longperiod (40-100 seconds) waveforms and compared with focal parameters derived from global teleseismic data. Using shorter periods (10-100 seconds) we estimate the shear and compressional velocity structure of the crust and uppermost mantle. Results are broadly consistent with previous studies and imply relatively little crustal thickening beneath the central Anatolian Plateau. Crustal thickness is about $35 \mathrm{~km}$ in western Anatolia and greater than $40 \mathrm{~km}$ in eastern Anatolia, however the long regional paths require considerable averaging and limit resolution. Crustal velocities are lower than typical continental averages, and even lower than typical active orogens. The mantle Pwave velocity was fixed to $7.9 \mathrm{~km} / \mathrm{s}$, in accord with tomographic models. A high subMoho Poisson's Ratio of 0.29 was required to fit the Sn-Pn differential times. This is suggestive of high sub-Moho temperatures, high shear wave attenuation and possibly partial melt. The combination of relatively thin crust in a region of high topography and high mantle temperatures suggests that the mantle plays a substantial role in maintaining the elevation.
\end{abstract}

\section{Introduction}

The Anatolian Plateau is a region of high elevation that results from continental collision of the Arabian Plate with Southern Eurasia. Convergence is accommodated by strike-slip motion along the Northern and Eastern Anatolian Faults and thrusting in the Caucasus Mountains. Among the outstanding issues regarding the large-scale tectonics of this region is the presence and extent of crustal thickening, the role of the mantle in maintenance of the high topography and the structure and composition of the crust and mantle and its relationship to continental volcanism. 
The seismic structure of this region has been studied with a variety of techniques and several features are noteworthy. One might expect the crust to be relatively thick, however receiver functions at station ANTO (Ankara, Turkey) imply a crustal thickness of only 36-38 km (Sandvol et al., 1998; Saunders et al., 1998). In northeastern Turkey the crust thickens from north to south from 32-40 km (Cakir et al., 2000). A crustal thickness of $40 \mathrm{~km}$ has been inferred for the entire Anatolian Plateau from surface wave group velocities (Mindevalli and Mitchell, 1989), however resolution of the Moho depth from surface wave dispersion is poor. Some studies report lateral variations between the crustal structure and thickness of eastern and western Anatolia (Mindevalli and Mitchell, 1989; Saunders et al., 1998). While the inferred normal crustal thickness of the Anatolian Plateau seems at odds with the high topography, hot buoyant mantle may certainly play a role. Low P-wave velocities (Chen et al., 1980; Hearn and Ni, 1994) and high S-wave attenuation, possibly related to partial melt, is reported for beneath the central Anatolian Plateau (Kadinsly-Cade et al., 1981; Rodgers et al., 1997; Gok et al., 2000). More normal sub-Moho P-wave velocities are inferred beneath northeastern Turkey (Necioglu et al., 1981). Surprisingly no velocity models have been inferred from regional waveform modeling. While receiver function and surface wave analysis can estimate shear wave velocities, waveform modeling the shear coupled P-wave, PL, can constrain average crustal compressional velocities.

In this report, we present preliminary analysis of complete regional waveforms (body- and surface waves) for paths sampling the Anatolian Plateau. Focal parameters are inferred from the regional data filtered at long-periods so as to reduce the sensitivity to velocity model. Generally good agreement is found between focal parameters from regional and teleseismic data, however a discrepancy in depth for one event is found. Seismic velocity models are reported for the region. The velocity models imply moderate crustal thickening from west to east. Crustal velocities are lower than typical continental averages, but consistent with active orogenic regions. The sub-Moho Poisson's Ratio is relatively high (0.29) compared to normal continental mantle, making it appealing to speculate that high temperature and possibly partial melt are present in the shallow mantle. These preliminary results show that future work with data from a dense regional network will reveal more conclusive evidence regarding the structural details of the Anatolian Plateau.

\section{Data}

Broadband three-component waveform data for events in 2000 were collected from open sources. We obtained data from the IRIS-GSN stations GNI (Garni, Armenia) and KIV (Kislovosk, Georgia) and the GEOFON/MEDNET stations ISP (Isparta, Turkey) and MALT (Malatya, Turkey). Three events occurring within the plateau were considered (Figure 1). These three moderately large events have reported focal mechanisms, depths and moments from the Harvard CMT (Centroid Moment Tensor) Project and USGS-NEIC (United States Geological Survey - National Earthquake Information Center). Focal mechanism, depth and seismic moment are necessary for matching absolute amplitudes of observed data to synthetic seismograms. In the next 
section we estimate focal parameters from the regional waveforms alone and compare our solutions to the reported teleseismic solutions.

\section{Focal Parameters from Long-Period Waveforms}

Seismic moment tensors and focal mechanisms have been estimated from sparse broadband networks (Dreger and Helmberger, 1993; Ritsema and Lay, 1995) and single stations (Walter, 1993; Fan and Wallace, 1991). Accuracy in the seismic velocity model is imperative in order to reliably estimate source parameter from intermediate period data (50-5 seconds), especially when using a single station or for small events (Dreger and Helmberger, 1993; Fan and Wallace, 1991). We use the grid search method of Walter (1993) to estimate the best double-couple mechanism, depth and moment for single and multiple station cases. For the moderately large events $\left(5.0 \geq \mathrm{M}_{\mathrm{W}} \geq 6.0\right)$ considered in the Anatolian Plateau we can use long-periods (40-100 seconds) and reduce the sensitivity to (unknown) crustal structure. We used an ad hoc model to compute Greens' functions with a reflectivity code (Randall, 1994).

Figures 2 and 3 show the source parameter waveform fitting for the 2000/158 and 2000/350 events, respectively. The long-period waveforms show excellent signal-tonoise and clear arrivals (Figures $2 \mathrm{a}$ and $3 \mathrm{a}$ ). The mechanisms are estimated for a number of depths and the minimum in scaled error indicates the best fit (Figures $2 b$ and $3 b$ ). Focal mechanisms are compared to the reported USGS-NEIC and CMT solutions (Figures $2 \mathrm{c}$ and $3 \mathrm{c}$ ) and show good agreement. In the following section we will use the USGS-NEIC estimates of the focal mechanism, depth and moment for waveform modeling, to avoid possible bias by our use of a possibly inappropriate velocity model.

There is a great discrepancy in the reported depths of the 2000/320 event by the USGS-NEIC $(66 \mathrm{~km})$ and Harvard CMT $(15 \mathrm{~km})$. An event at such great depth seems highly unlikely given the low velocities and high temperatures in the sub-crustal lithosphere in eastern Turkey. We tried unsuccessfully to model this event with complete three-component regional waveforms from stations MALT, GNI and KIV using the same methods described above. We unable to fit very late arriving energy, even at very long periods. We found evidence for a secondary event after the reported origin time. Figure 4 shows the autocorrelation functions for the raw vertical component broadband velocity recordings at GNI, KIV and MALT. There is a secondary peak on all three autocorrelations at 17-18 seconds. We speculate that the P-wave from a second event 17 18 seconds after the reported origin could be misidentified as a depth phase for an event with a depth of $66 \mathrm{~km}$. Travel times for the ak135 model (Kennett et al., 1995) predict a teleseismic pP-P differential time with this value for a $66 \mathrm{~km}$ depth. It is possible to model these observed regional waveforms as two events by summing the Green's functions with the suspected delay time and finding the optimal moments, depths and focal mechanisms by grid search.

\section{Lithospheric Structure}


Complete regional waveforms (body- and surface waves) are strongly impacted by the source focal mechanism and depth as well as the structure through which they pass. However if the source parameters are well constrained then the observed waveforms can be used to estimate structure. The large amplitude surface waves are mostly sensitive to the crustal thickness and shear velocities of the lithosphere. The body-waves, Pn and Sn, are mostly sensitive to the shallow mantle P- and S-wave velocities, respectively. The shear-coupled P-wave, PL, is strongly impacted by crustal thickness and average crustal $\mathrm{P}$-wave velocities and weakly sensitive to the S-wave structure. Matching observed waveforms to synthetic seismograms is widely done to estimate path-averaged one-dimensional structure. The fits can be good when the source is well modeled and paths are isolated to a more-or-less homogenous tectonic province.

We estimated one dimensional path-averaged velocity structures for paths sampling the Anatolian Plateau by fitting the observed three-component waveforms. A grid search scheme was employed to map out the fit of the data to a wide range of models (Rodgers and Schwartz, 1998; Rodgers et al., 1999). While grid search is computationally intensive, because the forward problem must be solved many times, it has the advantage of not requiring linearization, iteration or estimates of a starting model. Our goal is not to find complex layered crustal models that optimally fit the data, but rather to obtain robust estimates of bulk structure. The results of this study can be used to compute Green's functions for waveform modeling estimates of source parameters of new events or as starting models for waveform inversion for pure-path structure.

Synthetics were computed for each path for simple crustal models composed of a sediment layer, a single uniform crustal layer and a mantle. The crustal thickness and crustal P-wave velocity were varied with $5 \mathrm{~km}$ and $0.1 \mathrm{~km} / \mathrm{s}$ increments, respectively. The Poisson's Ratio in the crust was fixed at 0.25 and the mantle structure was held fixed. The synthetics were summed using both the USGS and CMT focal mechanisms and the misfit between the data and synthetic was computed in several period bands. The misfit is plotted on the model space in Figure 5. This shows the trade-off between crustal thickness and velocity along directions of constant vertical crustal travel time. While the best fit (indicated by the star) provides the minimum misfit, adjacent solutions with slightly higher misfit are acceptable. We found the best fits using the CMT and USGS solutions for the 2000/158 and 2000/350 events, respectively.

Figure 6 shows the velocity models and fits to the data. We chose models that in some cases may not have given the least misfit, but rather fit smaller amplitude features. In particular, the large amplitude Love wave observed on most paths tends to dominate the sensitivity of the data to the models. We found that smaller amplitude Rayleigh wave features were better fit on the models adjacent to the misfit minima in Figure 5. The fits to the Rayleigh waves are disappointing, however this is not surprising given the severe under-parameterization. Clearly multiple layers and gradients in the crust will better fit the dispersion of the surface waves. Future work will address this issue. The bulk crustal $\mathrm{P}$-wave velocities are rather low $(5.8-5.9 \mathrm{~km} / \mathrm{s})$. The average $\mathrm{P}$-wave velocity of the continental crust is $6.45 \mathrm{~km} / \mathrm{s}$ with orogenic regions having a slightly lower average of $6.39 \mathrm{~km} / \mathrm{s}$ (Christensen and Mooney, 1995). 
The mantle P-wave velocity was fixed to $7.9 \mathrm{~km} / \mathrm{s}$, consistent with the average of tomographic models (Hearn and Ni, 1994; Sandvol personal communication; McNamara personal communication). In order to fit the long-period Sn arrivals, the sub-Moho Poisson's Ratio was set to 0.29 . This is somewhat higher than the stable continental average of 0.27 (Christensen and Mooney, 1995). These relatively low sub-Moho P- and S-wave velocities, high Poisson's Ratio and poor short-period Sn propagation suggest that high temperatures and possibly partial melt are present in the shallow mantle beneath the Anatolian Plateau.

\section{Conclusions}

In this study we report preliminary models of the lithosphere of the Anatolian Plateau. Results suggest that the crustal thickness is relatively typical of the continents, despite the high elevation of the Plateau. Crustal velocities are lower than stable continental regions, and a bit lower than typical active orogens. Sub-Moho velocities are low and the Poisson's Ratio is high, suggesting that high temperatures and possibly partial melt play a role in maintaining the high elevation of the Anatolian Plateau. Future work using events recorded in Turkey can improve resolution of seismic velocities and crustal thickness and address pending tectonic issues regarding the Anatolian Plateau.

\section{Acknowledgments}

Data was obtained from internet sites run by the Incorporated Research Institutes for Seismology Data Management System (IRIS-DMC) and the GeoFurschungsNetz (GEOFON) Program. This work was performed under the auspices of the U.S. Department of Energy by Lawrence Livermore National Laboratory under contract W7405-Eng-48.

\section{References}

Cakir, O., M. Erduran, H. Cinar and A. Yilmazturk, Forward modeling receivers functions for crustal structure beneath station TBZ (Trabzon, Turkey), Geophys. J Int., 140, 341-356.

Chen, C.-Y., W.-P. Chen and P. Molnar (1980). The uppermost mantle P-wave velocities beneath Turkey and Iran, Geophys. Res. Lett., 7, 77-80.

Christensen, N. and W. Mooney, 1995. Seismic velocity structure and composition of the continental crust: A global view, J. Geophys. Res., 100, 9761-9788.

Dreger, D. and D. Helmberger (1993). Determination of source parameters at regional distances with three-component sparse network data, J. Geophys. Res., 98, 8107-8125. 
Fan, G. and T. Wallace (1991). The determination of source parameters for small earthquakes from a single, very broadband seismic station, Geophys. Res. Lett., 18, 13851388.

Gok, R., N. Turkelli, E. Sandvol, D. Seber and M. Barazangi (2000). Regional wave propagation in Turkey and surrounding regions, Geophys. Res. Lett., 27, 429-432.

Hearn, T. and J. Ni (1994). Pn velocities beneath continental-collision zones: the TurkishIranian Plateau, Geophys. J. Int., 117, 273-283.

Kadinsky-Cade, K., M.Barazangi, J. Oliver and B. Isacks (1981). Lateral variation in high-frequency seismic signals at regional distances across the Turkish and Iranian Plateaus, J. Geophys. Res., 86, 9377-9396.

Kennett, B. L. N., E. R. Engdahl and R. Buland, Constraints on seismic velocities in the Earth from travel times, Geophys. J. Int., 122, 108-124, 1995.

Mindevalli, O. and B. Mitchell (1989). Crustal structure and possible anisotropy in Turkey from seismic surface wave dispersion, Geophys. J Int., 98, 93-106.

Necioglu, A., B. Maddison and N.Turkelli (1981). A study of the upper mantle structure of northwestern Turkey, Geophys. Res. Lett., 8, 32-35.

Randall, G. (1994). Efficient calculation of complete differential seismograms for laterally homogeneous earth models, Geophys. J. Int., 118, 245-254.

Ritsema, J. and Lay, T. (1995). Long-period regional wave moment tensor inversion for earthquakes in the western United States, J. Geophys. Res., 100, 9853-9864.

Rodgers, A., and S. Schwartz (1998). Lithospheric structure of the Qiangtang Terrane, northern Tibetan Plateau, from complete regional waveform modeling: evidence for partial melt, J. Geophys. Res., 103, 7137-7152.

Rodgers, A., Walter, W., Mellors, R., Al-Amri, A. M. S. and Zhang, Y. -S., 1999. Lithospheric structure of the Arabian Shield and Platform from complete regional waveform modeling and surface wave group velocities, Geophys. J Int., 138, 871-878.

Sandvol, E., D. Seber, A. Calvert and M. Barazangi (1998). Grid search modeling of receiver functions: Implications for crustal structure in the Middle East and North Africa, J. Geophys. Res., 103, 26,899-26917.

Saunders, P., K. Priestley and T. Taymaz (1998). Variations in the crustal structure beneath western Turkey, Geophys. J Int., 134, 373-389. 
Walter, W. (1993). Source parameters of the June 29, 1992Little Skull Mountain earthquake from complete regional waveforms at a single station, Geophys. Res. Lett., 20, 403-406.

\section{Table 1.}

Reported focal parameters.

\begin{tabular}{llllll}
\hline Date & Time & Latitude & Longitude & Depth & $\mathrm{m}_{\mathrm{b}}$ \\
\hline 2000/158 June 6 & $02: 41: 49.8$ & 40.621 & 32.967 & 3 & 6.1 \\
2000/320 Nov 15 & $15: 05: 39.3$ & 38.650 & 42.949 & 61 & 5.7 \\
2000/350 Dec 15 & $16: 44: 45.1$ & 38.614 & 31.058 & 5 & 6.0 \\
\hline
\end{tabular}

Location and origin time taken from the USGS-QDE (taken from the USGS-NEIC webpage http://www.neic.usgs.gov)

\begin{tabular}{lllllll}
\hline \multicolumn{1}{c}{ Event } & \multicolumn{3}{c}{ USGS-NEIC } & \multicolumn{3}{c}{ Harvard CMT } \\
\hline Date & Depth & $\mathrm{M}_{\mathrm{w}}$ & Strike/Dip/Rake & Depth & $\mathrm{M}_{\mathrm{W}}$ & Strike/Dip/Rake \\
\hline $2000 / 158$ & 3 & 6.1 & $122 / 69 /-106$ & 15 & 6.0 & $126 / 62 /-119$ \\
$2000 / 320$ & 66 & 5.7 & $108 / 11 /-95$ & 15 & 5.6 & $109 / 71 / 122$ \\
$2000 / 350$ & 5 & 6.0 & $98 / 57 /-106$ & 15 & 6.0 & $103 / 57 /-100$ \\
\hline
\end{tabular}

Taken from the USGS-NEIC webpage http://www.neic.usgs.gov and Harvard CMT webpage http://www.seismology.harvard.edu/CMTsearch.html )

\section{Table 2.}

Focal parameters from this study.

\begin{tabular}{llll}
\hline Date & Depth & MW & Strike/Dip/Rake \\
\hline $2000 / 158$ & 10 & 6.04 & $111 / 41 /-156$ \\
$2000 / 350$ & 5 & 6.17 & $120 / 25 /-56$ \\
\hline
\end{tabular}



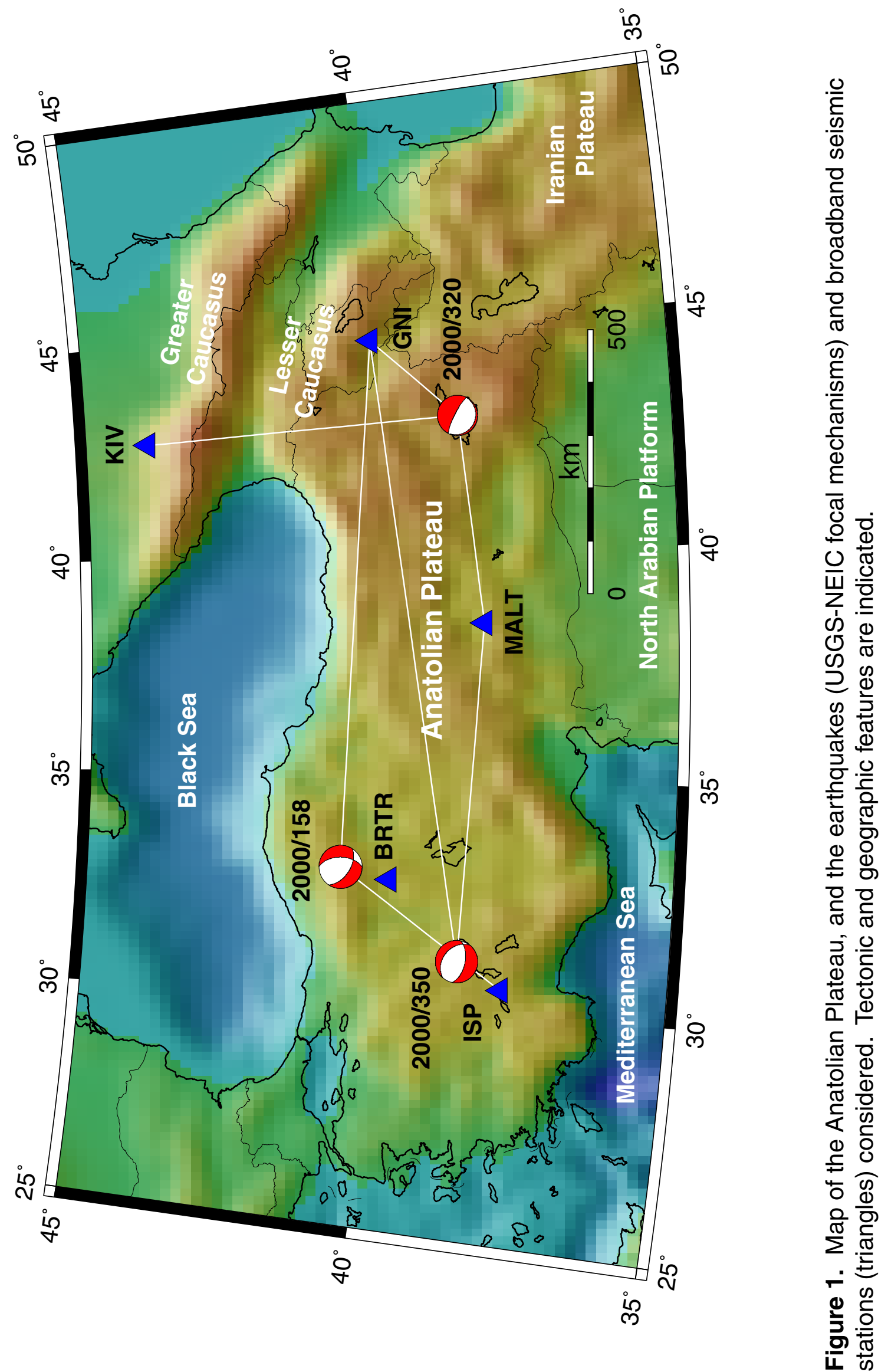

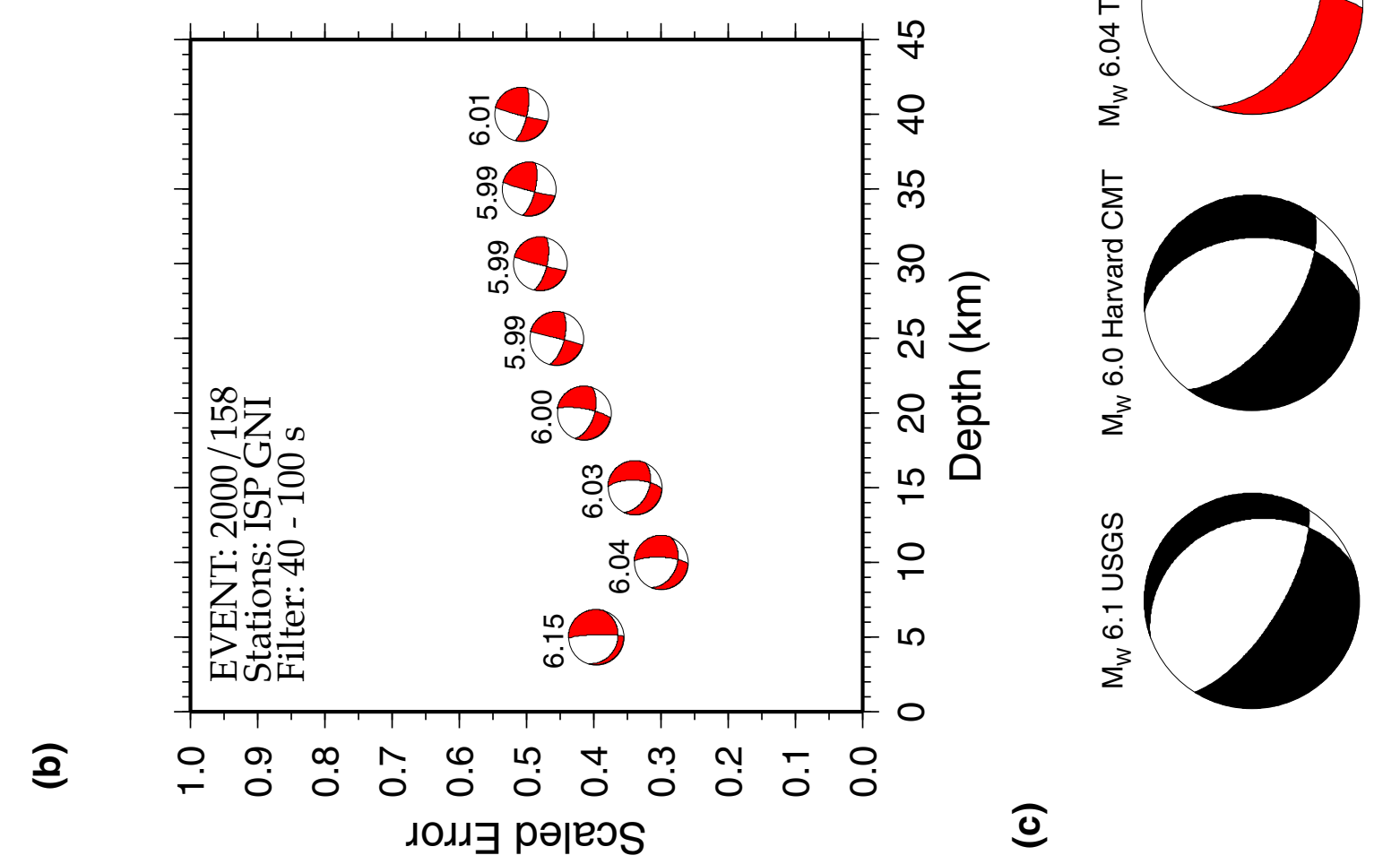

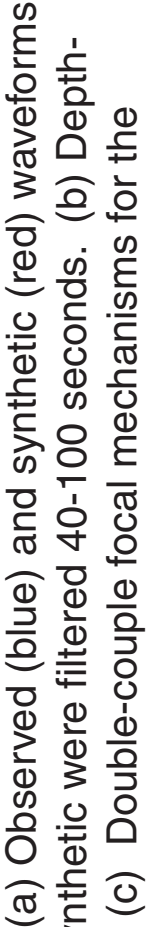

+ं के

ปั

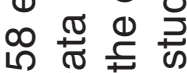

ᄃㄴ응

ᄋㅇㅇㅇㅝ
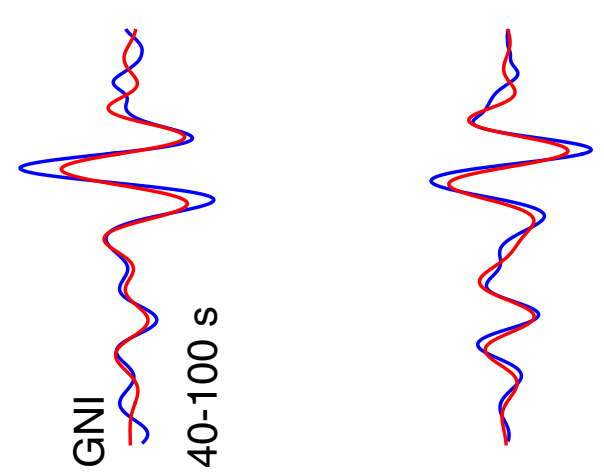

$N$

$\simeq$
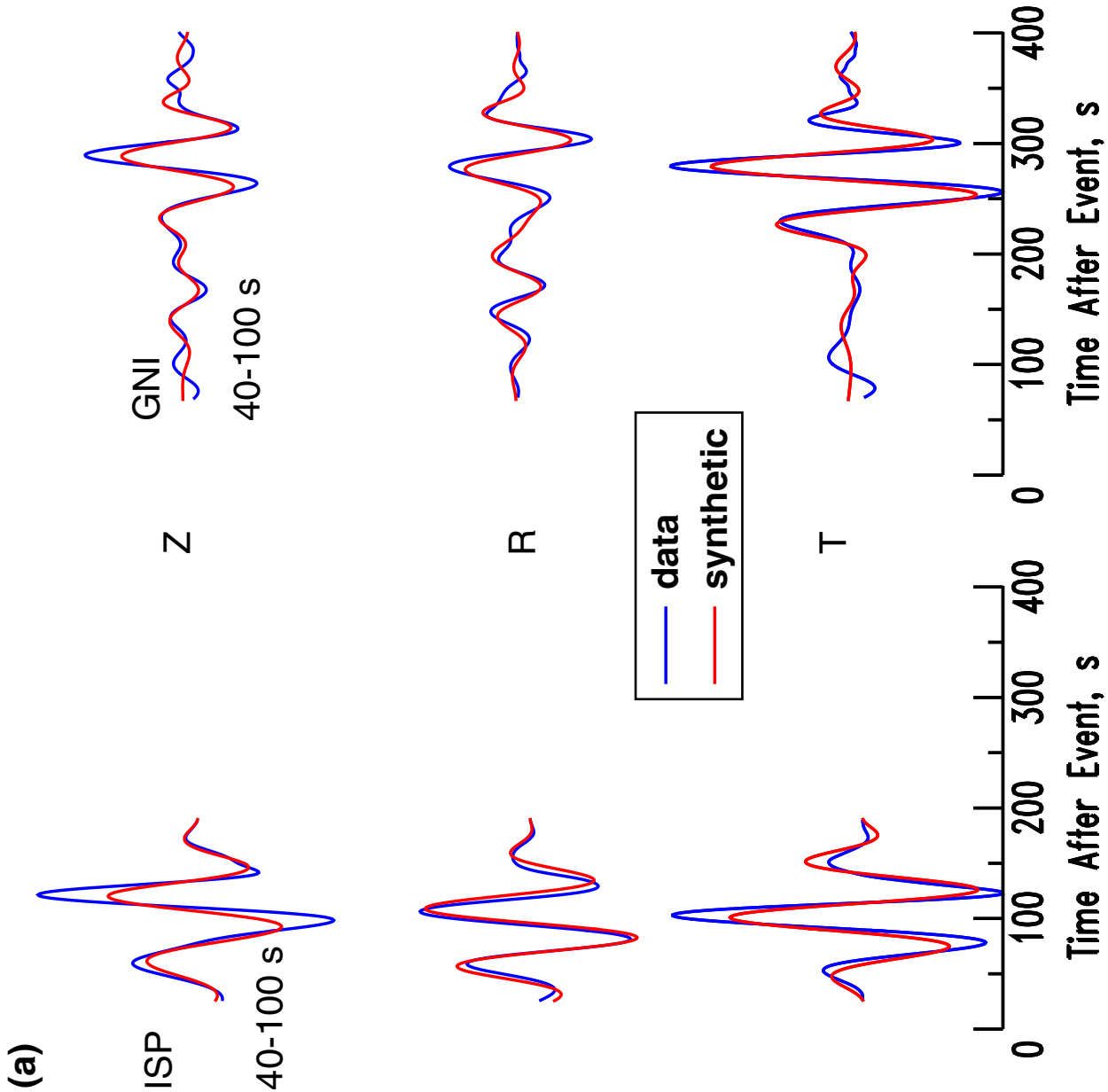

o

(1).

$\risingdotseq \infty$ के

ర

ஸ 응 ᅯ

屯 른

ह ه

은

ส్ర

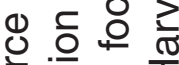

눋도

क 트 윰

(1) क ज

$\mp 0$ ए

ㅎㅡㄹㅀㄴㅣ

○ Ф

है

ब。 ప 心

으는

ह तల

ह 윙

은드으

Q 으 훙

त $\frac{\pi}{\omega} \frac{\Phi}{\pi}$

$\zeta$ है

ง

(1) 0 정

는

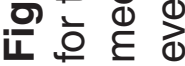




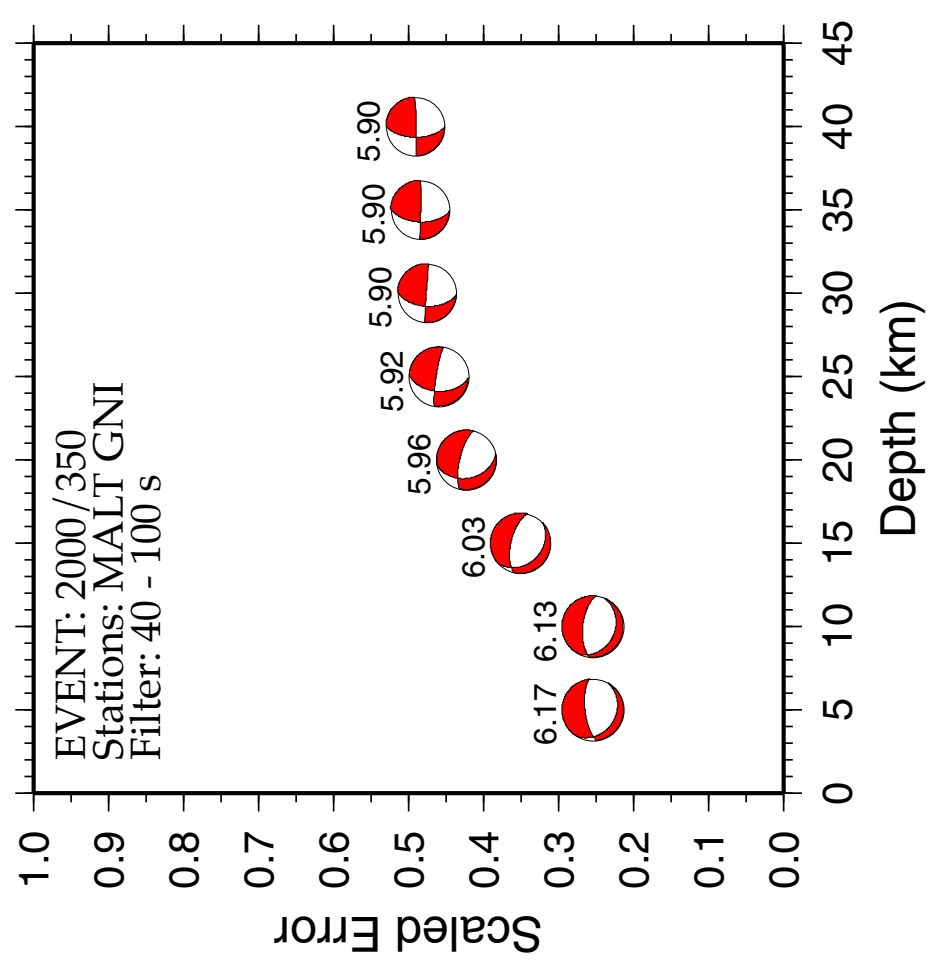

a 10ג

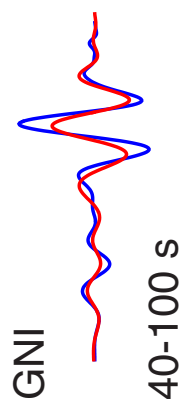

$N$

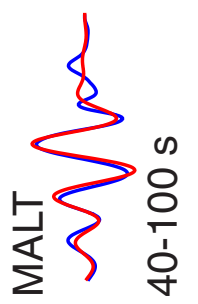

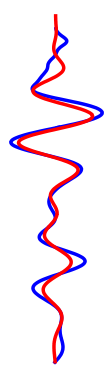

ه

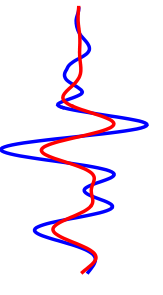

o

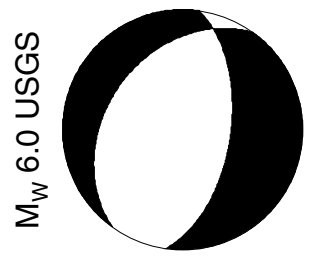

ํㅗㅇ

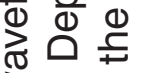

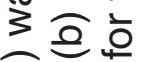
ठิ 응 屯 萦尔 के 은 $\frac{\varepsilon}{\pi}$ 땅요 일 잉 뜽 흐롱 ర잉 닌 ⿻ О음 खิ잉 में ญ

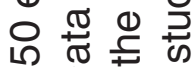

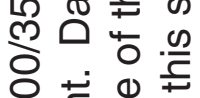

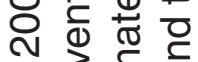

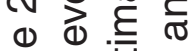
은 识 का o

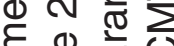
\% 行 등ㅇㅇㅇㅝ

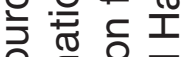
क ه के के

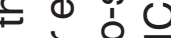

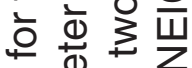

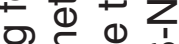
에

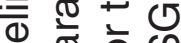
흥 으윽 저요 $\varepsilon$ 응 흔 政

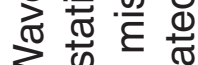
3 . ल 全 o 政

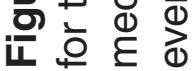




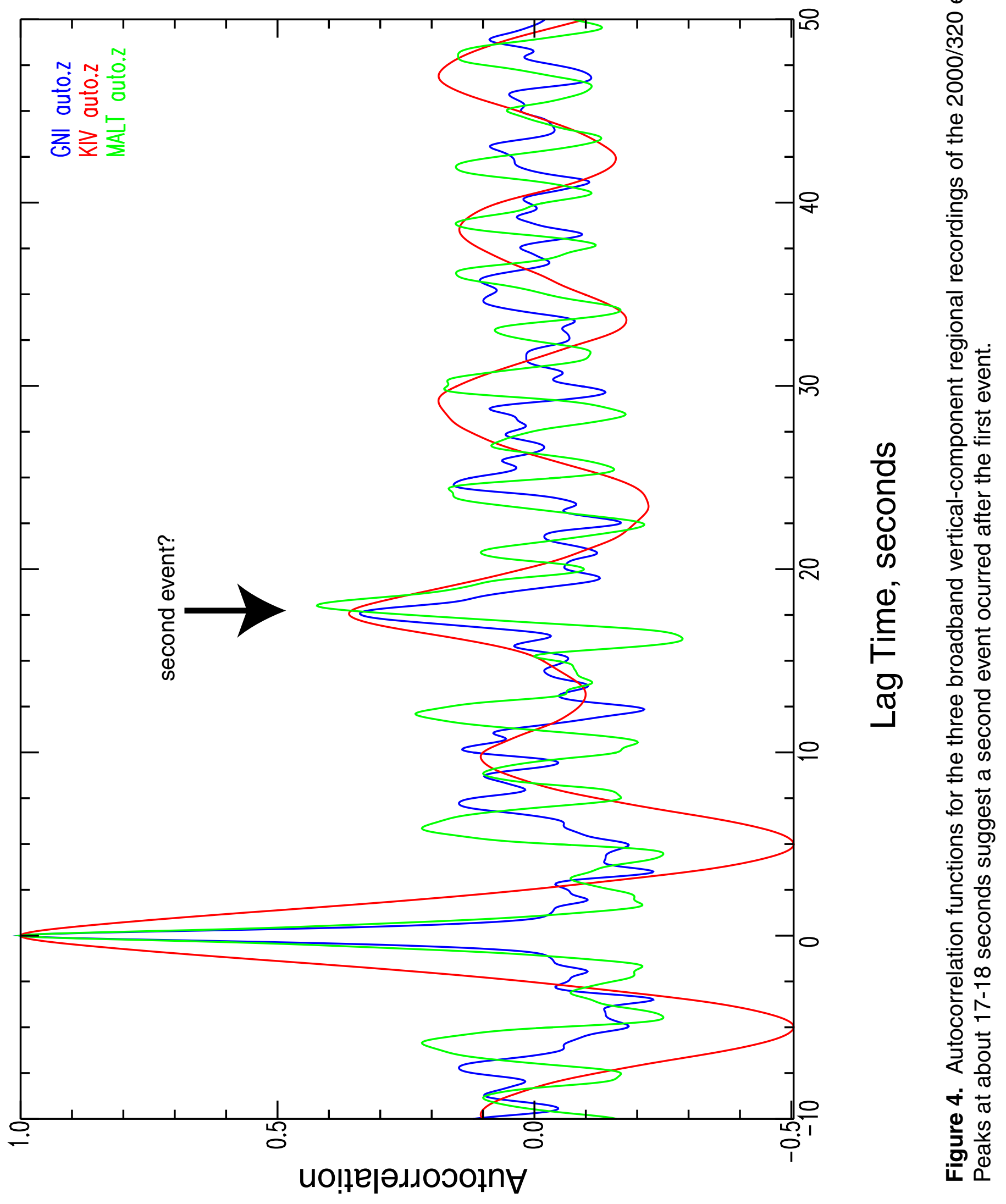



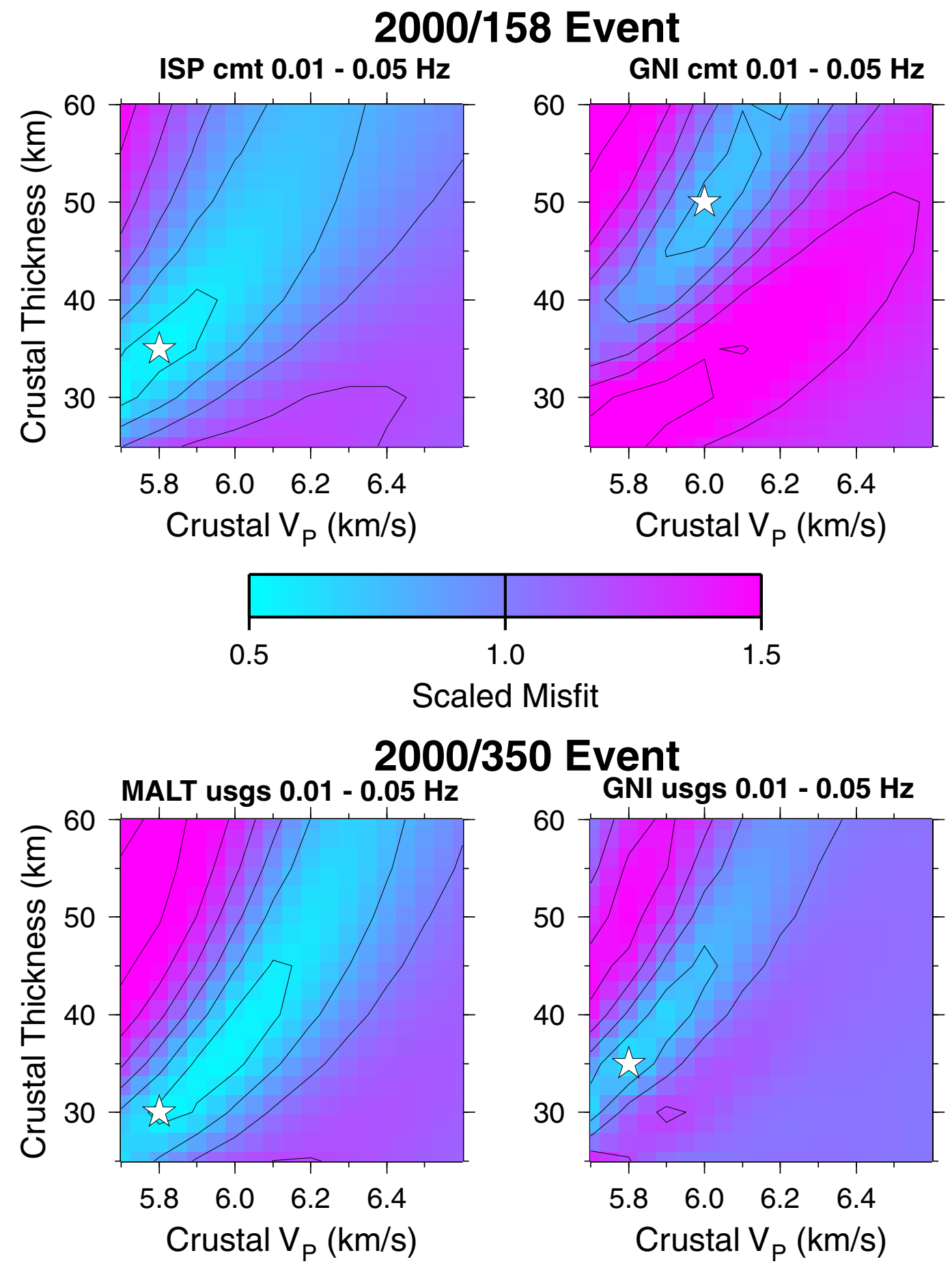

Figure 5. Misfit surfaces for three-component complete waveform fits to simple crustal models (a) 2000/158 and (b) 2000/350 events. The scaled misfit (data-synthetic) is plotted on the crustal thickness-crustal velocity model space (contour interval 0.2 ). The best-fit model (minimum misfit) is indicated by the star. A crustal Poisson's ratio of 0.25 was used for all models. 


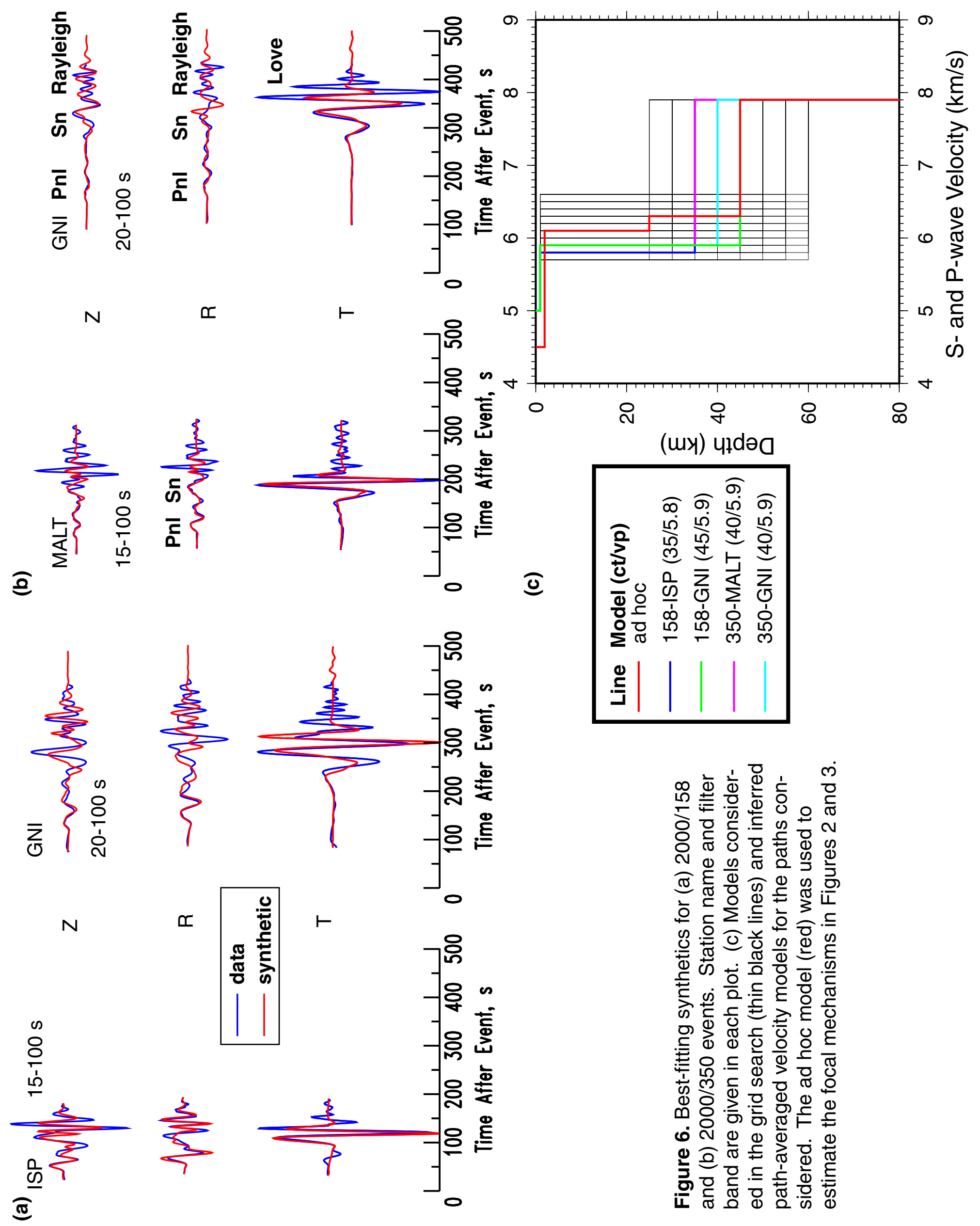

